\title{
Directions of Formation of Favorable Competitive Environment in Azerbaijan's Leasing Services Market
}

\author{
Sevda Mammad Huseynova \\ International Center for Graduate Education, Azerbaijan State University of Economics (UNEC), Baku, Azerbaijan
}

Received October 23, 2020; Revised December 12, 2020; Accepted February 1, 2021

\section{Cite This Paper in the following Citation Styles}

(a): [1] Sevda Mammad Huseynova, "Directions of Formation of Favorable Competitive Environment in Azerbaijan's Leasing Services Market," Universal Journal of Accounting and Finance, Vol. 9, No. 1, pp. 116 - 121, 2021. DOI: 10.13189/ujaf.2021.090112.

(b): Sevda Mammad Huseynova (2021). Directions of Formation of Favorable Competitive Environment in Azerbaijan's Leasing Services Market. Universal Journal of Accounting and Finance, 9(1), 116 - 121. DOI: 10.13189/ujaf.2021.090112.

Copyright $C 2021$ by authors, all rights reserved. Authors agree that this article remains permanently open access under the terms of the Creative Commons Attribution License 4.0 International License

\begin{abstract}
The article is dedicated to investigating existing competitive environment in the Azerbaijani leasing market, analyzing criteria and indicators characterizing it, identifying the ways in which the leasing company's marketing policy will be enhanced, and disclosing directions for the formation of a competitive environment in the country's market. For this purpose, the author has examined the major aspects of theoretical competition in the article, highlighting the competitive advantages of the leasing services market as well as the elements of the marketing mechanism that effectively operates in the market (price policy, frequency of services provided by leasing companies, intensity of consideration of initial leasing documents and claims), terms and conditions of leasing deals, advanced information technologies, corporate information systems, including the use of the Internet), the features of price formation for leasing services were disclosed, and SWOT analysis of Azerbaijani leasing market was conducted. In addition, the article highlights the importance of choosing the main strategic directions and competitive methods in the leasing services market, and has made relevant proposals to improve the leasing company's marketing policy as well as the formation of a favorable competitive environment in the leasing market of Azerbaijan as a whole.
\end{abstract}

Keywords Leasing, Services Market Competitive Advantages, Competitive Environment, Price Formation, Marketing Policy

\section{Introduction}

In most of the companies and organizations intending to use leasing, a number of important issues appear, as one of the most attractive financial instruments for solving issues of renewal of key production assets. For example, do leasing business operators have the option of free choice, and which leasing companies are eligible to interact with, taking into account their business conduct? All these issues are directly related to the problems of competition in the leasing services market.

\section{Theory and Literature Review}

Leases has existed throughout the history of mankind. Examples are reflected in the Babylonian cuneiform plates [5]. In the Roman Empire, lawyers considered agricultural land, urban dwellings and private property as objects of leases $[9,10]$.

Today the economic literature provides data related to the economic aspects of leasing, such as equipment rental, business and leasing control [12]. In civilized countries, leases is perceived as a special form of contract. Leasing is an important tool for economic development [2]. Number of studies have been conducted on leases and leasing services, as well as analyses on the example of various countries. Today, the leasing market is on the agenda.

There are interesting reseach and opinions about the impact of lending on the economy [9] and financing 
Micro and Small Business Enterprises [1].

Selection of the price formation method in the leasing services market depends on both corporate interests and competition in the market. Well-known competitor Robin Cooper focuses on three major aspects of competition: price, quality and functionality [13]. It can be logically considered that these components are directly related to competition in leasing business.

Because prices and quality are more standardized, competition sharply turns around leasing services functionality. This situation is characterized by flexible competition. This means that the strategic success of the leasing as a whole is that companies are finding that they are quiet and hasty in dealing with new projects and sources of financing for these projects [15].

The achievement of a larger share in the market is not always a goal for economic entities, including leasing. First of all, the company directed to the maximum value for its proprietors must meet the following conditions:

- Profitability;

- Positive cash flow;

- High profitability from capital investment;

- Not only high accounting profit, but also high economic profit.

\section{Competitive Advantages in Leasing Services Market}

Professor of Harvard University, Michael Porter called these factors competitive advantages [14]. John Dale, a well-known consultant in the field of assessment, thinks that effective price formation is the basis of competitive advantage [16].

We consider that Azerbaijani leasing companies should be more prone to the advantages of the following rates at the current stage of economic development. These advantages include the elements of a marketing mechanism, which directly work from the very first days in the market:

1. Price policy. Based on this, leasing companies offer various offers to the market using price manipulation for their products.

2. The intensiveness of the services provided by the companies that are in the leasing relationship, the consideration of the initial leasing documents and claims.

3. The term of signing of leasing agreement. Of course, the size of the monthly lease payments is dependent in this process, and this does not assume little significance to the choice of a company for the customer. It should be noted that, while determining the lease term, the leasing company takes the lease's liquidity, its value, and other factors.
4. The use of advanced information technologies, corporate information systems, including the use of the Internet.

Information about competitors is not limited to information about the prices offered only on leasing services offered. To compete, you need to have information about the conditions that are set by leasing companies- information about the types of products, contract terms, advance payments, and real increasing in leasing.

Formation of prices for leasing services is a strategic activity aimed at long-term prospect, as well as long-term outcomes that takes into account both consumers' and competitors' reaction. The price decisions of leasing companies can be taken in a number of circumstances, proceeding from the interests of signing of any certain agreement. However, this is a tactical decision, which, as a rule, is intended to maximize its profit or, to the contrary, comprise to the leasing agent.

The western countries have the practice of applying indicators that characterize the level of competition through the concentration and monopolization of the market. Thus, the US uses these indicators to make it clear that state authorities must be aware of the necessity of intervention to market mechanisms. Demand for such intervention occurs while considering market power rate of one or more enterprises, or more correctly, their excessive effects on their prices and production volumes.

The concentration ratio is used to measure market power. This ratio represents the share of four large enterprises in the field of production. In the case of net monopoly, the concentration will be about $100 \%$, while in the competitive period it will be close to zero.

According to the estimates of American economists Paul Samuelson and William Nordrose, the high degree of concentration is that the share of four large companies in total production exceeds $60 \%$. Low concentration occurs when the share of four large companies in the total output is less than $20 \%$.

If the leasing company enters the market now or introduces a new type of service to the market, all the information about competitors is important. Therefore, the competitors' cardboard should be created in a definite way and it should be renewed and completed on a regular basis.

In the leasing services market, information collected on competitors can be quantitative and qualitative or actual and subjective.

As a rule, quantitative information answers the following questions:

- What kind of organizations can be competitors of the company?

- What services do companies provide, how and in what areas do these services?

- Who are the main customers of the companies? 
- How do companies integrate their services into the market, how do they create favorable conditions for selling services?

However, the availability of emotional or quality features is crucial in evaluating of the services in the leasing service market due to the individual acceptance of services and by whom. Such information will always depend on it.

Qualitative characteristics can be included recognition of the entity, the professionalism of the staff, the quality of the service, the customer's loyalty, the entity's management, the marketing strategy and other non-formal indicators.

When it's time to collect real information, the peculiar analysis of many aspects of the opposing side requires intensive mental work.

In the leasing services market, collection of information about the opposing party is very different, and this is related to the creativity and professionalism of the company's staff. It is possible to create a list of opponents by utilizing many sources of information, adverts, and publications in the media.

Nowadays, it is not difficult to gather data on the most advanced enterprises in the leasing market with information and communication technology, mainly from the websites of the mentioned enterprises. Even it is also possible to get more useful information about competitors by using the services of the opponent party.

Collecting the above-mentioned information becomes easier when the service market is expanded to the area different from the product market. More precisely, this market is considered to be a local market. This is due to the fact that the service is not felt: it is also impossible to carry the services.

In the leasing service market, general information about the work with information systems is also applicable to information collected on competitors: it is necessary organizing the systematic gathering, evaluation of information, analyzing this information by experts, and organizing transmission of information to decision-makers.

However, it is required to consider the form of creating cardboard cards and its ways of checking it over time. When it comes to competitive advantage in the leasing service market, it is understood that sensory and non-sensitive rare assets belong to the firm. Competitive advantages are a different kind of activity where the strategy of business is very important factor to win the competition. Competitive advantages arise when the company earns more than the average income of its competitors or the market segment.

While defining competitive advantages in the leasing service market, referencing to customer inquiries, it is needed to ensure that competitive advantage is perceived by the company's customers. It is very characteristic for Azerbaijan that the enterprise believes that it has competitive advantages, but the consumer is unaware of it.

Practically, we can see that, depending on the characteristics of the field and the market, there are many types of competitive advantages. In today's competitive environment, the company has to have several (4-5) competitive advantages as a rule. The competitive advantages of the leasing service market may be as follows:

- Famous name;

- Professionalism and practice of employees;

- High quality of service;

- Personal contact with customers;

- Putting the consumer, his inquiries and desires into the foreground;

- Favorable conditions for the sale of favorable advertising and services;

- Development of branches, admission points;

- Being in a strategic area;

- Good material base (staff, money, equipment);

- Additional service complex.

Taking into account these factors, it is expedient to note that the SWOT analysis of Azerbaijan's leasing market is as follows in the table below. 
Table 1. SWOT analysis of leasing market of Azerbaijan

\begin{tabular}{|c|c|}
\hline Strength & Opportunities \\
\hline $\begin{array}{l}\text { 1. State support to leasing programs in priority areas of economy. } \\
\text { 2. Uniform licensing and adaptation of leasing legislation } \\
\text { 3. Tax, amortization, customs, investment concessions and privelage } \\
\text { when implementing leasing projects } \\
\text { 4. Simplification of judicial and administrative procedures during the } \\
\text { confiscation of leasing subject from unfair leasing holder. } \\
\text { 5. Transition of Leasing Companies to International Financial } \\
\text { Reporting Standards (IFRS). } \\
\text { 6. State-specific partnership during leasing operations }\end{array}$ & $\begin{array}{l}\text { 1. The use of leasing as one of the effective instruments in the } \\
\text { implementation of strategic, nation-wide and regional } \\
\text { development programs } \\
\text { 2. Introducing new leasing programs, products and services } \\
\text { 3. Diversification of financing sources of leasing activities, } \\
\text { including Islamic finance. } \\
\text { 4. Extensive use of the stock market mechanism for the } \\
\text { development of leasing services } \\
\text { 5. Creating conditions for the active involvement of foreign } \\
\text { investments }\end{array}$ \\
\hline Weakness & Threats \\
\hline $\begin{array}{l}\text { 1. Unsteadiness of existing (commercial) leasing companies in the } \\
\text { market } \\
\text { 2. The unsteadiness and shortage of the leasing companies' stock base } \\
\text { 3. Lack of "long" and "large" money in the investment process } \\
\text { 4. Insufficient transparency of leasing companies } \\
\text { 5. Absence of qualitative statistical reporting and information } \\
\text { 6. Insufficient branching of commodity, field, and regional structure of } \\
\text { leasing contracts }\end{array}$ & $\begin{array}{l}\text { 1. Strong foreign leasing companies' access to the Azerbaijani } \\
\text { market } \\
\text { 2.Unsteadiness of leasing legislation } \\
\text { 3. Increase in inflation, increased cost of financial resources } \\
\text { attracted by leasing companies } \\
\text { 4. Deterioration of the quality of assets and leasing portfolio as a } \\
\text { whole, increasing the risks of leasing operations }\end{array}$ \\
\hline
\end{tabular}

\section{Selection of Basic Strategic Directions in Leasing Services Market}

As a rule, competitive advantage can be considered as the basis for a separate leasing company strategy. The general direction of the leasing services market can be summarized as follows:

- low-cost strategy; Nevertheless, it should be noted that competitive advantage prevails when low costs are achieved at the expense of less production costs compared to competitors;

- differentiated service strategy, i.e. the strategy of adapting the service to the needs of specific consumer groups;

- A strategy of innovative companies offering new services.

It is clear from the above that the company can more accurately determine its position in the market on the basis of analysis of competitive environment in leasing services market, and as a result, the company's position in the market can be strengthened and its successes can be further enhanced.

Comprehensive information about competitors helps to compare and regularly analyze the quantity and quality of leasing services, allows the market service experience of the leasing service company to be more competitive.

Regardless of the level of development of market relations in the republic, the fight against monopoly in the market and protection of competition are the main directions of the state's economic regulation function. The fight against unfair competition is regarded as an urgent matter regardless of the law of the leasing services market, the tradition of traditions and culture.

Competition is one of the factors influencing the production and sale of production facilities in the leasing market. In competition, prices and non-price methods are used. Price competitiveness leads to economic pragmatism in the market, and non-price competition improves sales methods, concessions, and advertising. It is important to note the importance of price and tariff regulations in this area.

There are conditions for the expansion of production of leasing services in our republic. However, demand for these products is currently being paid mainly through imports. Organization of competitive leasing services in our republic is one of the main tasks ahead. The competition fight reflects the natural state of market relations and is critical to the development of the competitive market. Competitiveness is also crucial in accelerating scientific and technical progress, as well as promoting the application of progressive forms of labor organization. In the market economy, domestic producers face with competitive environment in the domestic market rather than in foreign markets. One of the main tasks in this regard is to develop a competitive environment in the market. As a mechanism providing macroeconomic balance in the market economy, our country has created a necessary legislative base for competition development (the Constitution of the Republic of Azerbaijan, Anti-Monopoly Activity, Laws of Unfair Competition, Law on Advertising, etc.).

\section{Leasing Company's Marketing Policy and Its Improvement}

Distinctive features of the leasing company's other business activities have a direct impact on the leasing company's marketing activity. The leasing company's marketing policy implies the marketing functionality of all levels of the leasing process and the implementation process of marketing philosophy and tools at all levels of the leasing process, which involves the realization of the marketing function in order to generate and reclaim the 
demand and the interests of the firm.

Relations with customers, banks, insurance companies are long-term and stable, where relationships with customers are largely discrete in leasing transactions. Thus, in the sphere of leasing services, marketing combines the principle of service marketing with respect to consumers, as well as the mutual influence marketing in relation to the remaining counterparties. This is conditioned by the specific features of the leasing.

From a marketing point of view, the mutual influence in the leasing industry is not only an essential element of entrepreneurial activity in the implementation of a business project, but also a prerequisite for contractual relations between all subjects of the leasing process, and allows each of them to achieve a certain level of profits through exchange of performance and results in long-term establishment of relations.

The mutual impact marketing for the leasing company demonstrates the multifaceted development of mutually beneficial forms of cooperation in the leasing industry, which is aimed at simultaneous involvement and use of all resources (human, mental, financial and material) to meet the requirements of the key leaseholders.

In order to achieve this, it is necessary to continually reconcile the marketing tools used with the changing requirements of the enterprise structure.

When formulating a marketing policy, a leasing company can use many marketing strategies. One of the most important types of leasing company's successful activity is the provision of financial efficiency. Here, key marketing strategies are strategies for increasing revenue and strategies to increase sales volumes.

A number of marketing strategies are used by leasing companies: additional functional development strategies (operational leasing, staff leasing); strategies for choosing perspective investment projects; a strategy to attract private equity and to attract less financial resources; a closer interaction strategy with suppliers; strategy for mastering new segments; commodity diversification strategy; a unique specialty strategy; portfolio diversification strategies; customer service strategy.

Stable positive trends in the Azerbaijani economy stimulate leasing companies to adopt new customer segments, especially through the introduction of new leasing services in the world. In addition, reducing marginal earnings of a leaser promotes strengthening of the company's marketing interest in the expansion of the portfolio, as well as intensifying the development of the product and the overall customer service level.

As for the number of leasing companies in Azerbaijan, the issue of their specialization is undoubtedly topical, as is the case in other countries where this sphere has already gained momentum. It can also be linked to the development of the non-oil sector in the strategic direction. Local leasing companies can be involved in serving certain government projects that will be implemented in various sectors of the sector.

\section{Result of Research}

1. We believe that the main factor of the success of the leasing company in the market is the understanding of the marketing as integrated

Thus, it is offered to look at marketing within the leasing service in several ways:

- Leasing companies' marketing activities are a tool for managing decision-making to ensure the company's long-term and sustainable success. Improving its marketing policy envisages a change in the organization that creates the competitive advantage of the leasing company. Therefore, it is necessary to apply the standards of the company's restructuring and the procedure for the provision of leasing services.

- The leasing company's marketing activities should be viewed as a set of measures to interact with hardware suppliers and financial insiders. Here, marketing focuses on the acquisition of competitive advantages through a market-specific marketplace.

- Marketing activities in the leasing services industry should be viewed as the principle of the company's activity, consisting of the entire business of the enterprise consistently directed to the needs and needs of potential consumers. The leasing company applies a customer-oriented approach, where marketing is governed by the principle of enterprise management. Clients for leasing provide customers with leasing services understanding of their customers' needs and finding solutions to their problems. In this case, it is necessary to take into account market competitive advantages in relation to the price, quality and timing of the leasing service.

2. It is expedient to reflect the leasing opportunities of the national road map and its key sectors in the currently developed strategic roadmap. As it is well known, special attention is paid to priority directions of development of non-oil sector of Azerbaijan economy. It is necessary to note the creation of regional innovation zones in Azerbaijan, especially technics and agrarian parks of high technologies. In this regard, great prospects are opened for leasing. Thus, the main means of residents of these high-tech production facilities can be organized and can then be upgraded through leasing. Additionally, with the help of leasing, their goods and services can be realized in domestic and foreign markets. Therefore, in the development of technological and agropark development programs, in our opinion, it is necessary to consider the full potential of leasing business in solving their creation and activity.

3. Cancellation of VAT assigned for imported leasing objects in 2016 can be considered the most important 
step taken in this area. Thus, as most leasing companies failed to compete with banks because of VAT, the portfolio of leasing companies was transferred to the hands of banks. The adoption of this decision can be regarded as commendable. It is also important that such a decision be taken too soon to the real sector.

4. There is a great need for intensification of leasing application in the agrarian sphere. The Agroleasing Company is currently financed by the state budget on favorable terms. Leasing of technical equipment to the agrarian sector entrepreneurs with a low interest or interest rate would further strengthen this process. However, the lack of proper functioning in this area is a delay in the current process. Therefore, it is absolutely necessary to attract other leasing companies to that process. As a result of the benefits of the Agroleasing privileges and concessional financing, fair competition is created and the difficulties in obtaining the equipment they require are being abandoned.

5. Innovative leasing products should be brought to the republic in order to ensure the leasing development and achieve its international presence. Implementation of Islamic leasing in the country may be a new stage in the development of leasing sector in Azerbaijan. First of all, it is necessary to train the skilled cadres of the country in order to bring the Islamic leasing, or rather, the lease to Azerbaijan.

Development of the leasing sector in Azerbaijan can play a key role in the development of national economy. This, in turn, can ensure domestic demand and stimulation of export-oriented production.

\section{REFERENCES}

[1] Addisu Karafo "Role of Equb in Financing Micro and Small Business Enterprises in Konso" Universal Journal of Accounting and Finance Vol. 5(1), pp. 1 - 8 DOI: 10.13189/ujaf.2017.050101
[2] Carter, Laurence W. 1996. Leasing in Emerging Markets. Washington D.C.: The World Bank. worldbank.org

[3] Contino, Esq., Richard M. The Complete Equipment-Leasing Handbook: A Deal Maker's Guide with Forms, Checklists and Worksheets, Second Edition (Volume 2) 2nd Edition, 2015

[4] David G. Mayer, Business Leasing For Dummies? 2001

[5] Ellickson, Robert C. \& Charles DiA. Thorland. 1995. Ancient Land Law: Mesopotamia, Egypt, Israel. 71 Chicago-Kent Law Rev. 321-411. Iit.edu

[6] Eric Cumlev, 7 Secrets to Successful Apartment Leasing. 1996, Published bv Hara Pub Group (1996). ISBN 10: 1883697441 ISBN 13: 9781883697440.

[7] Frank J. Fabozzi and Peter K Nevitt, Equipment Leasing. 2000, ASIN : B0087BO9SI: Publisher : Wiley, John \& Sons, Incorporated (January 28, 2000).

[8] Frier, Bruce W. 1980. Landlords and Tenants in Imperial Rome. Princeton, N.J.: Princeton University Press.

[9] Hui Yang, Mohammad Meysami, Alex Meisami, "A Rising Market and Capital Structure Decisions" Universal Journal of Accounting and Finance 5(4): 102-108, 2017 http://www.hrpub.org DOI: 10.13189/ujaf.2017.050404

[10] Kehoe, Dennis P. 1997. Investment, Profit, and Tenancy: The Jurists and the Roman Agrarian Economy. Ann Arbor, MI: University of Michigan Press.

[11] Robin Kooper when Lean Enterprises Collide.- Boston, Harvard Busines School Press, 1995.

[12] Thomas W. Merrill 2020. The Economics of Leasing. Journal of Legal Analysis, Volume 12, 2020, Pages 221-272

[13] Газман В.Д. Ценообразование лизинга. Учебное Пособие.-М.:ГУ ВШЭ, 2006, 148 с.

[14] Дейли Джон. Эффективное иенообразование - основа конкурентного преимущества: Пер. с англ. - М.: Издательский дом «Вильямс», 2004.

[15] Портер М. Конкурентное преимущество. Как достичь высокого результата и обеспечить его устойчивость / Майкл Е. Портер; Пер. с англ.- Альпина Бизнес Букс, 2005.

[16] Самуэльсон Пол Э., Нордхаус Вильям Д. Экономика: Пер. с англ.- М:Издательский дом «Вильямс», 2003. 